\title{
PENAMPILAN REPRODUKSI SAPI POTONG LOKAL DI KECAMATAN BOLAANG KABUPATEN BOLAANG MONGONDOW
}

\author{
Brenda Boda, A. Lomboan, J.F. Paath, M.J. Hendrik
}

Fakultas Peternakan Universitas Sam Ratulangi Manado, 95115

\begin{abstract}
ABSTRAK
Penelitian ini bertujuan untuk mengetahui penampilan reproduksi sapi potong lokal di Kecamatan Bolaang Kabupaten Bolaang Mongondow. Penelitian ini menggunakan sapi potong lokal milik petani peternak yang di ambil secara sampel di beberapa desa di Kecamatan Bolaang Kabupaten Bolaang Mongondow. Penelitian ini menggunakan metode Survey dengan pengumpulan data primer dan sekunder. Analisis data mengenai variabel yang di teliti menggunakan analisis deskriptif dengan mengacu pada model pengukuran setiap variabel. Hasil penelitian menunjukkan bahwa Service per conception 1,38, Conception rate $70 \%$, Lama kebuntingan 276,47, Umur beranak pertama 32,022, dan Calving interval 375,26. Berdasarkan hasil penelitian yang di lakukan dapat disimpulkan bahwa penampilan reproduksi ternak sapi potong lokal di kecamatan Bolaang kabupaten Bolaang Mongondow sudah baik.
\end{abstract}

Kata kunci: Reproduksi, Sapi Potong, Kecamatan Bolaang

Korespondensi (Corresponding Author)

Email: alomboan@unsrat.ac.id

\section{ABSTRACT}

REPRODUCTIVE PERFORMANCE OF LOCAL BEEF COWS IN BOLAANG DISTRICT OF BOLAANG MONGONDOW REGENCY. This study aims to determine the reproductive performance of local beef cattle in Bolaang District, BolaangMongondow Regency. This study used local beef cattle owned by breeders who were taken as samples in several villages in Bolaang District, Bolaang Mongondow Regency. This study used a survey method to obtain primary and secondary data collection. Data analysis regarding the studied variables used descriptive analysis referring to the measurement of each variable. The results showed that service per conception was 1.38, conception rate was $70 \%$, pregnancy period was 276.47 days, animal age of first calving was 32.022 months, and calving interval was 375.26 days. Based on these results of study, it can be concluded that the reproductive performance of local beef cattle in Bolaang district, Bolaang Mongondow regency was categorized into normal reproductive performance of local beef cattle.

Key word: Reproduction, Local beef cow, Bolaang district, 


\section{PENDAHULUAN}

Di Indonesia sapi potong merupakan bagian penting dalam sistem pertanian terpadu dan kehidupan peternak rakyat. Peningkatan jumlah penduduk, menyebabkan permintaan terhadap daging khususnya daging sapi terus meningkat.

Program pemerintah telah dicanangkan melalui Kementerian Pertanian untuk memenuhi kebutuhan daging sapi yaitu program swasembada daging sapi berbasis sumberdaya genetik (Ditjennak, 2010). Program tersebut secara umum bertujuan untuk menambah populasi dan produktivitas sapi, dengan mengembangkan potensi persapian Indonesia yang ada (Harmini et al., 2011).

Sapi potong adalah sapi yang dipelihara dengan tujuan utama sebagai penghasil daging, sehingga sering disebut sebagai sapi pedaging. Sapi potong di Indonesia merupakan salah satu jenis ternak yang menjadi sumber utama pemenuhan kebutuhan daging setelah ayam. Kebutuhan protein hewani di Indonesia yang cenderung meningkat setiap tahun seiring dengan terus meningkatnya laju pertambahan penduduk, maka perlu adanya kesinambungan peningkatan produksi peternakan. Program peningkatan produksi ternak yang dilakukan pemerintah merupakan salah satu usaha untuk mengejar target akan kebutuhan gizi terhadap protein hewani bagi masyarakat. Usaha peternakan sapi potong adalah jenis usaha dibidang peternakan yang sangat potensial untuk dikembangkan dan diproduksi dalaEm jumlah yang cukup untuk memenuhi kebutuhan masyarakat (Lubis, 2000).

Permintaan daging sapi dari tahun ketahun terus meningkat. Tahun 2019 konsumsi daging di Indonesia sebanyak 686.270 ton yang dipasok dari ternak lokal sebanyak 58\% dan $42 \%$ diimpor dari Negara lain. Populasi sapi potong di seluruh Indonesia pada tahun 2019 sebanyak 18,12 juta ekor (Ditjennak, 2019). Hal tersebut membuktikan bahwa masih kurang produksi daging di Indonesia. Berbagai upaya telah dilakukan pemerintah untuk menghasilkan sapi di dalam negeri, berbagai macam bangsa sapi potong telah diimpor baik berupa ternak hidup maupun dalam bentuk semen beku yakni dengan IB, yang bertujuan untuk meningkatkan mutu genetik sapi potong di Indonesia (Susilawati, 2011).

Salah satu usaha untuk mengatasi masalah tersebut adalah perlu dilakukan usaha peningkatan kemampuan reproduksi ternak sapi. Penampilan reproduksi yang diamati antara lain melalui service per 
conception $(\mathrm{S} / \mathrm{C})$, conception rate $(\mathrm{C} / \mathrm{R})$, lama kebuntingan, umur beranak pertama, dan calving interval (CI) (Desinawati dan Isnaini, 2010). Penampilan reproduksi dapat digunakan untuk menghitung waktu siklus perkembangbiakan ternak yang ada dapat digunakan untuk memperkirakan populasi ternak di masa yang akan datang (Leksanawati, 2010).

Kabupaten Bolaang Mongondow khususnya di Kecamatan Bolaang memiliki potensi wilayah berupa padang pengembalaan yang cukup luas dan hijauan pakan ternak sehingga cukup potensial untuk pengembangan ternak sapi potong. Pada tahun 2017 ternak potong di Kecamatan Bolaang yaitu 1.773 ekor (BPS, 2017). Akan tetapi penelitian mengenai kinerja reproduksi sapi potong di wilayah ini belum pernah dilakukan.

Berdasarkan permasalahan di atas telah dilaksanakan penelitian mengenai penampilan reproduksi sapi potong di Kecamatan Bolaang, Kabupaten Bolaang Mongondow.

\section{METODE PENELITIAN}

\section{Waktu dan Lokasi Penelitian}

Penelitian ini di laksanakan pada bulan Juli sampai Agustus 2019 dan bertempat di Kelurahan Inobonto, Desa
Langagon, Desa Bangomolunow yang di tentukan berdasarkan jumlah pemilikan ternak di Kecamatan Bolaang, Kabupaten Bolaang Mongondow.

\section{Materi Penelitian}

Materi yang digunakan dalam penelitian ini adalah sapi potong lokal milik petani peternak yang di ambil secara sampel di beberapa desa di Kecamatan Bolaang Kabupaten Bolaang Mongondow.

\section{Populasi dan Sampel}

\section{Populasi}

Populasi dalam penelitian ini adalah seluruh ternak sapi yang ada di Kecamatan Bolaang Kabupaten Bolaang Mongondow.

\section{Sampel}

Pemilihan desa sampel secara sengaja (purposive) dengan pertimbangan desa yang memiliki populasi ternak sapi potong lokal terbanyak yaitu Kelurahan Inobonto, Desa Langagon, dan Desa Bangomolunow, Sampel ternak sapi yang di teliti yaitu ternak sapi potong yang telah dua kali beranak di masing-masing desa sampel, sebanyak 30 ekor sapi per desa.

\section{Metode Penelitian dan Pengumpulan Data}

Metode penelitian yang digunakan dalam penelitan ini adalah metode Survey dengan pengumpulan data primer dan 
sekunder. Data primer di peroleh dari hasil wawancara (berpedoman pada daftar pertanyaan/kuisioner yang telah disiapkan sesuai susunan variabel) dengan sejumlah peternak yang memiliki sapi potong (induk). Sedangkan data sekunder diperoleh dari berbagai instansi terkait dengan penelitian ini seperti dinas peternakan, monografi kecamatan, kantor statistik.

\section{Variabel yang akan diteliti}

Variabel yang akan di amati pada ternak sapi potong di Kecamatan Bolaang Kabupaten Bolaang Mongondow.

\section{Service Per Conception}

Service per Conception (S/C) adalah angka yang mununjukkan berapa kali perkawinan atau inseminasi buatan yang dibutuhkan oleh ternak sampai menghasilkan kebuntingan (Hartatik et al., 2009)

$\mathrm{S} / \mathrm{C}=$ Jumlah inseminasi jumlah sapi betina yang bunting.

\section{Conception Rate}

Conception Rate (CR) adalah jumlah induk yang positif bunting dibagi jumlah ternak betina akseptor (Hafez, 2000).

$\mathrm{C} / \mathrm{R}=$ Jumlah betina bunting kawin pertama (ke-1) jumlah ternak akseptor

\section{Lama Kebuntingan}

Lama kebuntingan adalah periode dari mulai terjadinya fertilisasi sampai terjadinya kelahiran normal yang diukur melalui jarak antara perkawinan yang subur dengan kelahiran (Iskandar, 2011).

\section{Umur beranak Pertama}

Umur beranak pertama adalah umur sapi saat mengalami beranak yang pertama kalinya (Foldager, 1988).

\section{Calving Interval}

Calving Interval adalah jarak waktu atau lamanya waktu suatu masa kelahiran ke masa kelahiran berikutnya (hari) Ball and Peters (2004). Calving Interval (bulan) = kelahiran ke-i - kelahiran ke(i-1). Calving Interval $($ hari $)=$ periode kebuntingan + days open

\section{Analisis Data}

Analisis data mengenai variabel yang diteliti menggunakan analisis deskriptif.

\section{HASIL DAN PEMBAHASAN}

\section{Gambaran Umum Lokasi Penelitian}

Kabupaten Bolaang Mongondow merupakan salah satu kabupaten di Provinsi Sulawesi Utara. Ibukota Kabupaten Bolaang Mongondow adalah Lolak, berjarak sekitar 200,00 km dari kota Manado ibukota Provinsi Sulawesi Utara. Jika dilihat dari letak geografis Kabupaten Bolaang Mongondow terletak pada posisi $123^{\circ}{ }^{\circ} 1^{\circ}{ }^{\circ}$ BT dan 0॰ '30-100 LU B. Kabupaten Bolaang 
Mongondow merupakan wilayah yang terdiri dari pesisir, bukit dan daerah pegunungan yang memiliki ketinggian bervariasi. Wilayah yang tertinggi adalah Kecamatan Passi Timur dengan ketinggian 630 mdpl sedangkan wilayah kecamatan yang berada disekitar pesisir pantai hanya memiliki ketinggian 12 mdpl yaitu, Kecamatan Poigar, Bolaang, Bolaang Timur, Lolak dan Sangtombolang. Kabupaten Bolaang Mongondow memiliki luas wilayah sebesar $2.871,65 \mathrm{~km}^{2}$ dan jumlah penduduknya mencapai 246.282 jiwa dan sebaran penduduk 86jiwa $/ \mathrm{km}^{2}$. Kabupaten Bolaang Mongondow terdiri dari 15 Kecamatan, 2 Kelurahan, dan 200 Desa (BPS, 2019)

\section{Karakteristik Responden}

\section{Umur}

Umur merupakan salah satu faktor yang mempengaruhi produktivitas kerja seseorang. Presentase umur seserorang akan berpengaruh terhadap kemampuan dalam mengerjakan pekerjaan. Seiring bertambahnya umur maka akan mempengaruhi kemampuan fisik, sehingga terjadi penurunan produktivitas. Makatita (2013) mengemukakan bahwa banyaknya peternak yang berada pada kelompok umur produktif merupakan modal utama dalam pengembangan suatu usaha peternakan.
Hasil penelitian menunjukkan bahwa kisaran umur peternak cukup bervariasi yaitu antara 25-62 tahun, distribusi responden yang berumur di bawah 41 tahun sebanyak sepuluh peternak $(38,47 \%)$, respon peternak yang berumur antara 41 sampai 50 tahun sebanyak tujuh peternak $(26,92 \%)$ dan respon yang berumur lebih dari 50 tahun sebanyak sembilan peternak $(34,61 \%)$. Hal ini berarti bahwa peternak dilokasi penelitian berada pada kategori produktif (Makatita, 2013).

\section{Tingkat Pendidikan}

Hasil penelitian menunjukkan bahwa sebagian besar peternak yaitu lulusan sekolah dasar (SD) sebanyak sembilan orang $(34,61 \%)$, lulusan sekolah menegah pertama (SMP) sebanyak enam orang $(23,07 \%)$ lulusan sekolah menegah atas (SMA/Sederajat) sebanyak sepuluh orang $(38,47 \%)$, dan lulusan strata satu (S1) sebanyak satu orang $(3,85 \%)$. Tingkat Pendidikan responden di lokasi penelitian yaitu di kelurahan Inobonto desa Bangomolunow dan desa Langagon cukup bervariasi dan berimbang, Namun demikian masih didominasi oleh lulusan SMA/Sederajat. Hal ini menunjukkan cukup baiknya tingkat Pendidikan peternak di Kecamatan Bolaang Kabupaten Bolaang Mongondow. Tinggi rendahnya tingkat 
Pendidikan sangat mempengaruhi informasi yang masuk, tingkat pengetahuan, keterampilan, dan sikap peternak dalam kegiatan usahanya, sehingga dalam pelaksanaannya para peternak selain mengandalkan pengalaman yang ada, juga mampu mempelajari ilmu pengetahuan yang terus berkembang dalam dunia peternakan sapi potong.

\section{Penampilan Reproduksi Ternak Sapi Potong}

\section{Service Per Conception}

Service per conception (S/C) adalah angka yang menunjukkan berapa kali perkawinan sampai menghasilkan kebuntingan. Service per conception dalam penelitian ini diukur berdasarkan perkawinan secara alami atau kawin alam.

Hasil penelitian menunjukkan bahwa Service per conception di lokasi penelitian Kecamatan Bolaang adalah 1,38 artinya dari 90 ekor sapi rata-rata keberhasilan perkawinan sampai menghasilkan kebuntingan yaitu 1,38 perkawinan. Jainudeen dan Hafez, (2008), menyatakan bahwa Nilai S/C yang berkisar antara 1,6 sampai 2,0. Service per conception berpengaruh positif terhadap penampilan reproduksi Semakin rendah nilai S/C maka penampilan reproduksinya juga akan semakin baik. Makin rendah nilai S/C, maka makin tinggi kesuburan ternak betina tersebut (Pohontu et al., 2018). Dapat digambarkan bahwa S/C ternak sapi potong di Kecamatan Bolaang sudah ideal.

Angka S/C jika berada pada angka di bawah dua yang berarti sapi masih dapat beranak 1 tahun sekali, apabila angka S/C di atas dua akan menyebabkan tidak tercapainya jarak beranak yang ideal dan menunjukkan reproduksi sapi tersebut kurang efisien yang membuat jarak beranak menjadi lama.

\section{Conception Rate}

Conception rate adalah jumlah ternak betina yang bunting pada perkawinan pertama dari sejumlah ternak yang di kawinkan. Nilai CR di Kecamatan Bolaang sebesar $70 \%$ yang artinya dari 90 ekor sapi yang pertama kali dikawinkan $70 \%$ bunting atau 63 ekor sapi. Nilai tersebut sudah dapat dikatakan optimal. CR sapi PO di Kabupaten Malang sebesar 75,34\%. CR menentukan tinggi rendahnya efisiensi reproduksi dan jika CR mencapai nilai $65-75 \%$ maka nilai efisiensi reproduksi dianggap baik. Nuryadi dan Wahjuningsih (2011)

Tingginya nilai $\mathrm{CR}$ di lokasi penelitian juga di tunjukkan oleh rendahnya angka S/C yaitu 1,31, hal itu tidak lepas dari 
Tabel 1. Rataan S/C, C/R, Lama kebuntingan, Umur beranak pertama, Calving interval.

\begin{tabular}{ll}
\hline Variabel & Rata-Rata \\
\hline Service per conception (kali) & $1,38 \pm 0,01$ \\
Conception Rate (\%) & $70 \pm \underline{1}, 01$ \\
Lama Kebuntingan (hari) & $276,47 \pm 0,01$ \\
Umur Beranak Pertama (hari) & $32,022 \pm 0,01$ \\
Calving Interval (hari) & $375,26 \pm 0,01$ \\
\hline
\end{tabular}

pemberian pakan oleh peternak setiap hari dan pengetahuan peternak dalam pemeliharaan. Apriem (2013) menjelaskan bahwa tinggi rendahnya CR dipengaruhi oleh kondisi ternak, deteksi birahi dan pengelolahan reproduksi yang akan berpengaruh pada fertilitas ternak dan nilai konsepsi.

\section{Lama Kebuntingan}

Lama kebuntingan adalah periode dari mulai terjadinya fertilitas sampai terjadinya kelahiran normal yang diukur melalui jarak antara perkawinan yang subur dengan kelahiran. Lama kebuntingan ternak sapi potong dilokasi penelitian berada pada kisaran 270 sampai 285 hari, sebagian besar atau 56,67 ternak mengalami kebuntingan 275 hari. Secara keseluruhan rataan lama kebuntingan ternak yaitu 276,47 hari. Hal ini menunjukkan keadaan reproduksi ternak yang normal yaitu 276,47 hari, dimana telah dilaporkan dari beberapa penelitian bahwa lama kebuntingan ternak sapi bali maupun ongole tidak berbeda secara signifikan.

Menurut Prasojo et al. (2010), lama kebuntingan sapi bali berkisar antara 278,8 sampai 291 hari. Lama masa bunting sapi lokal berkisar antara 275-285 hari, sedangkan masa bunting sapi-sapi Eropa antara 240-330 hari dengan rata-rata 283 hari (Iswoyo dan Widiyaningrum, 2008). Variasi yang kecil pada lama bunting sapi lokal menunjukkan bahwa sapi-sapi lokal tersebut masih memiliki kekerabatan yang tinggi, sehingga pengaruh bangsa menjadi relatif kecil Penyebab lama bunting dipengaruhi oleh bangsa sapi, jenis kelamin dan jumlah anak yang dikandung, umur induk, musim dan letak geografis (Iskandar, 2011).

\section{Umur Beranak Pertama}

Umur beranak pertama adalah umur sapi saat mengalami beranak pertama kalinya. Hasil penelitian menunjukkan bahwa Umur beranak pertama di lokasi penelitian berada pada kisaran 28-34 bulan 
dengan presentase nilai berbeda-beda. Sebagian besar atau 54,44 ternak mengalami umur beranak pertama 33 bulan. Secara keseluruhan rataan umur beranak pertama di lokasi penelitian adalah 32,022 bulan. Umur beranak pertama ini masih termasuk dalam kategori baik berdasarkan standar Ditjen Peternakan (1992) yaitu antara 30-36 bulan. Hal ini sesuai dengan pendapat Desinawati et al. (2010) yang menyatakan bahwa umur pertama kali sapi peranakan Simmental melahirkan antara 28-32 bulan. Dalam artian bahwa umur beranak pertama di lokasi penelitian sudah dapat dikatakan ideal. Hal ini menunjukkan bahwa umur beranak pertama lebih muda dibandingkan umur beranak pertama sapi bali pada peternakan intensif di instalasi pembibitan pulukan yaitu 36,8 bulan (Siswanto et al. 2013).

\section{Calving Interval}

Calving Interval adalah jarak waktu atau lamanya waktu suatu masa kelahiran ke masa kelahiran berikutnya. Calving interval di lokasi penelitian memiliki nilai yang beragam yaitu berada antara 365-405 hari, dengan rata-rata CI 375,26 hari. Hasil penelitian menunjukkan jarak beranak sampai beranak berikutnya di lokasi penelitian sudah tergolong baik. Hal ini dapat disebabkan oleh, perkawinan yang tepat, serta nilai S/C yang rendah.

Calving interval menunjukkan variasi yang tidak begitu besar jika dibandingkan dengan hasil penelitian Iskandar dan Farizal (2011) yang menjelaksan bahwa jarak beranak induk sapi rata-rata 377 hari serta lebih tinggi bila dibandingkan dengan hasil penelitian Ihsan (2010) yang menyebutkan bahwa CI sapi PO rata-rata sebesar 410,3 hari dan sapi Peranakan Limousin sebesar 387,3 hari. Nilai CI pada penelitian ini sudah dapat dikatakan ideal, menurut pendapat Hadi dan Ilham (2004) bahwa jarak waktu beranak (CI) yang ideal adalah 12 bulan, yaitu 9 bulan bunting dan 3 bulan menyusui, hal ini ditambahkan oleh Ball and Peters (2004) bahwa efisiensi reproduksi dikatakan baik apabila seekor induk sapi dapat menghasilkan satu pedet dalam satu tahun.

\section{KESIMPULAN}

Berdasarkan hasil penelitian yang dilakukan dapat disimpulkan bahwa penampilan reproduksi ternak sapi potong lokal di Kecamatan Bolaang Kabupaten Bolaang Mongondow sudah baik 


\section{DAFTAR PUSTAKA}

Apriem, F,. 2013. Penampilan Reproduksi Sapi Peranakan Ongole Berdasarkan Paritas di Kota Probolinggo Jawa Timur. Thesis. Fakultas Peternakan. Universitas Brawijaya. Malang.

Ball, P.J.H. and Peters, A.R. 2004. Reproduction In Cattle Third Edition. Blackwell Publishing. Victoria. Australia.

Badan Pusat Statistik. 2017. Statistik Daerah Kecamatan Bolaang: Badan Pusat Statistik Kabupaten Bolaang Mongondow.

Badan Pusat Statistik. 2019. Statistik Daerah Kecamatan Bolaang: Badan Pusat Statistik Kabupaten Bolaang Mongondow.

Desinawati, N. dan N. Isnaini. 2010. Penampilan reproduksi sapi peranakan simmental di Kabupaten Tulungagung Jawa Timur. TERNAK TROPIKA Journal of Tropical Animal Production 11: 4147.

Ditjennak. 2010. Blue Print Program Swasembada Daging Sapi 2014. Jakarta: Direktorat Jenderal Peternakan, Kementan RI

Foldager, J., K. Serjsen, J.B. Larsan. 1988. Feed intake and growth in the rearing period as well as the milk production in the first lactation in heifers feed adlibitum with barley, food sugar beets and long barley straw. J. Dairy Sci. 61: 173.

Hadi, P.U. dan N. Ilham. 2002. Problem Dan Prospek Pengembangan Usaha
Pembibitan Sapi Potong di Indonesia. Jurnal Penelitian dan Pengembangan Pertanian 21(4): 148-157.

Harmini, H., R.W. Asmarantaka, dan J. Atmakusumah. 2011. Model dinamis sistem ketersediaan daging sapi nasional. J. Ekonomi Pembangunan: Kajian Masalah Ekonomi dan Pembangunan 12(1): 128-146

Hartatik, T., D. A. Mahardika, T. S. M. Widi dan E. Baliarti. 2009. Karakteristik dan kinerja induk sapi silangan Limousin-Madura dan Madura di Kabupaten Sumenep dan Pamekasan. Buletin Peternakan 3(3): 143-147.

Hafez, E.S.E., 2000. Reproduction in Farm Animal. 6 $6^{\text {th }}$ Edition. Lea and Febiger. Philadelpia.

Ihsan, M.N. 2010. Indeks fertilitas sapi PO dan persilangannya dengan limousin. TERNAK TROPIKA Journal of Tropical Animal Production 11(2): 82-87.

Iskandar, I. 2011. Performan reproduksi sapi PO pada dataran rendah dan dataran tinggi di Provinsi Jambi. Jurnal Imiah Ilmu-Ilmu Peternakan Vol XIV(1): 51-61.

Iswoyo, I. dan P. Widiyaningrum. 2008. Performans reproduksi sapi peranakan simmental (psm) hasil inseminasi buatan di Kabupaten Sukoharjo Jawa Tengah. Jurnal Ilmiah Ilmu-ilmu Peternakan. 11(3): 125-133.

Jainudeen, M.R. and Hafez, E.S.E. 2008. Cattle And Buffalo dalam Reproduction In Farm Animals. $7^{\text {th }}$ Edition. Edited by Hafez E. S. E. 
Lippincott Williams dan Wilkins. Maryland. USA.

Leksanawati, A. Y. 2010. Penampilan Reproduksi Induk Sapi Perah Peranakan Friesian Holstein di Kelompok Ternak KUD Mojosongo Boyolali. Skripsi. Fakultas Peternakan UNS.

Lubis, M.A. 2000. Pemberdayaan bioteknologi reproduksi untuk peningkatan mutu genetik ternak. Wartazoa 10(1): 1-6.

Makatita, J. 2013. Hubungan antara karakteristik peternak dengan skala usaha pada usaha peternakan kambing di Kecamatan Leihitu Kabupaten Maluku Tengah. Jurnal Agrinimal. 3(2): 80-84

Nuryadi, N. dan Wahjuningsih, S. 2011. Penampilan reproduksi sapi peranakan ongole dan peranakan limousine di Kabupaten Malang. TERNAK TROPIKA Journal of Tropical Animal Production 12(1), 76-81

Partodihardjo, S. 1987. Ilmu Reproduksi Hewan. Cetakan ke-2. Mutiara Sumber Widya, Jakarta.

Pohontu, A., A, Lomboan., J.F Paath., S.C. Rimbing. 2018. Penampilan reproduksi ternak sapi potong di Kecamatan Bintauna Kabupaten Bolaang Mongondow Utara. Zootec 38(1): $102-113$

Prasojo, G., I. Arifiantini, dan K. Mohamad. 2010. Korelasi antara lama kebuntingan bobot lahir dan jenis kelamin pedet hasil inseminasi buatan pada sapi Bali. Jurnal Veteriner 11(1):41-45.
Susilawati, T. 2011. Tingkat keberhasilan inseminasi buatan dengan kualitas dan deposisi semen yang berbeda pada sapi Peranakan Ongole. TERNAK TROPIKA Journal of Tropical Animal Production 12(2):15-24. 